\title{
Rockzenész, filmcsillag és cowboy: Sam Shepard, a „legamerikaibb” drámaíró
}

\author{
VARRó GABRIELLA: Mesterek árnyékában. Sam Shepard drámái és \\ a hagyomány, Debrecen, Debreceni Egyetemi Kiadó, 2013.
}

A legendás színpadi alakítások még elevenen élnek az amerikai drámát kedvelő magyar színházlátogatók emlékezetében: James Tyrone-t Várkonyi Zoltán hívta életre, Mensáros László Willy Lomant tette feledhetetlenné, Tolnay Klári játéka Blanche DuBois szerepében pedig máig maradandó élmény. Ugyanakkor az O’Neill-MillerWilliams triumvirátust követő új amerikai drámaíró nemzedék müveiről igen csekély ismerete van/lehet az érdeklődő magyar színházrajongónak és olvasónak, így nincsenek felidézhető szerepek sem. Jóllehet, az 1960-as években New York bohém- és művésznegyedében (Greenwich Village) kibontakozó alternatív színházi mozgalom fiatal írók sorát indította el a pályán, akik közül a legnagyobbak - Edward Albee (1928-), Sam Shepard (1943-) és David Mamet (1947-) - immár több mint fél évszázada meghatározó alakítói és megújítói az amerikai színház és dráma világának. Mégis, egyedül talán Albee neve cseng ismerősen Magyarországon. ${ }^{1}$ Ma már méltán nevezhetjük az Albee-Mamet-Shepard hármast a modern amerikai drámát megteremtő és világszínvonalra emelő „óriások”, Eugene O’Neill, Arthur Miller és Tennessee Williams örököseinek, hiszen az ifú nemzedék - új és sajátos eszköztárral - ugyanolyan felelősséggel és mélyrehatóan ábrázolja az amerikai ideálok elvesztését, ostorozza az amerikai lét és identitás zavaró és lefokozó vonásait, ahogy elődeik tették.

Varró Gabriella Mesterek árnyékában: Sam Shepard drámái és a hagyomány címü, 2013 karácsonyára megjelent könyve a „kanonikus ősapák” és a nemzedékváltó drámaírók keresztmetszetében helyezi el az egyik legeredetibb alkotó, a Pulitzer-díjas Shepard drámaművészetét és rajzolja meg drámaírói portréját. A kötetben közreadott, korábban angolul már publikált tíz tanulmány Shepard hét színművének sokoldalú elemzését tartalmazza a nagy elődök és a kortárs drámaírók egy-egy művének kontextusában. A hagyomány és eredetiség, a kontinuitás és megszakítottság vezérfonalára felfüzött egységes szempontrendszer érvényesítésével Varró azt vizsgálja, hogyan öröklődik át és újul meg Shepard alkotásaiban az elődök és a kortársak tematikája, formanyelve, ikonográfiája, illetve mennyiben volt termékenyítő hatású a becketti látásmód és dramaturgia a műveire. Az elvégzett komparatisztikai vizsgá-

\footnotetext{
${ }^{1}$ A Színháztudományi Intézet adatai szerint magyar színházakban 1945 után az említett amerikai szerzőktől bemutatott darabok száma a következő: O’Neill: 12; Miller: 15; Williams: 17; Albee: 11; Mamet: 3; Shepard: 5.
} 
latok módszertani elve az intertextualitás, mely a szerző értelmezésében nem szorosan vett szövegközeli elemzéseket jelent, hanem inkább a drámai, irodalmi, kulturális, mítoszi, pszichológiai vonatkozások és a társadalmi hagyományok tettenérését, melyek a kiválasztott Shepard-szövegekben átalakulnak és új értelmet nyernek. A választott értelmezési keretnek köszönhetően Varró egy sajátos 20. századi amerikai drámatörténetet (is) felvázol, amely mintegy végigköveti a tipikusan amerikai témák (nemzet- és identitásalkotó mítoszok hanyatlása, mitikus régiók eltűnése, család szétesése, Hollywood álomvilága, másságkonstrukciók), valamint karakterek (az ügynök archetípusa, a clown típusalakzata, a trickster alak, hösök és ellenhősök) búvópatakszerüen ismétlődő felbukkanását.

A szakmai-tudományos igénnyel megírt munka fontos forrásként szolgál az angol és amerikanisztika szakos főiskolai és egyetemi hallgatók számára, az amerikanisztikakutatásokat végzőknek, de haszonnal forgathatják a színházi szakma képviselői, valamint a kortárs amerikai kultúráról és irodalomról tájékozódni kívánó szélesebb olvasóközönség is. Magyar nyelvü amerikai drámatörténet hiányában a téma iránt érdeklődők mindeddig csupán Országh László és Virágos Zsolt Az amerikai irodalom története (1997) és Bollobás Enikő Az amerikai irodalom története (2005) vonatkozó részfejezeteiből, valamint a 2012-ben Cristian M. Réka szerkesztésében megjelent $A$ fattyú müvészet nyomában: Írások amerikai drámáról és színházról címü e-könyvből tudtak tájékozódni. Az utóbbi kiadvány magyar amerikanista kutatók tollából származó kilenc tanulmányt közöl a 20. századi amerikai dráma legkiválóbb íróiról.

A magyar olvasó számára hasznos adalékokkal és háttérinformációkkal szolgáló bevezetést a tényleges összevetéseket tartalmazó három nagy fejezet követi, világos elrendezésben. A bevezetés erénye, hogy tömören és irányok kijelölésével igazít el a külföldi és hazai Shepard-recepcióban, ugyanakkor kevésbé szerencsés kézzel kidolgozott Shepard bemutatása és a vizsgálat elméleti alapvetése. Figyelembe véve, hogy a több mint ötven - zömmel sikeres és díjakkal elhalmozott - színmüvet tartalmazó Shepard-korpuszból a kötet csupán hetet elemez (igaz, mélyrehatóan és sokoldalúan), bővebb kifejtést érdemelt volna Shepard kezdeti, kísérletező drámaíró termésének vázlatos áttekintése. Miként építi be az amerikai rockvilág, a cowboy-, horror- és westernfilmek motívumait ekkori műveibe? Hogyan hozza létre, alkotja meg önmagát ezekben a művekben? Shepard ugyanis egyszerre jazzdobos, rockzenész, filmszínész és drámaíró, majd forgatókönyvíró, film- és színházrendezö, és méltán lehet a „legamerikaibb” művésznek tekinteni énfelmondása, sokszínűsége és a színműveiben különösen megmutatkozó, az amerikai ideálok újraélesztésébe vetett rendíthetetlen hite okán. Ezek az ismeretek különös jelentőséget kap(hat)nak a zárófejezetben tárgyalt Kicking a Dead Horse (2007) szintetizáló, önvallomásszerü darabjának még árnyaltabb megértéséhez. A darab egyetlen szereplöje a vadnyugati sivatagban kóborló magányos Hobart Struther, egykori mükereskedő, aki a szerző értelmezésében Shepard alteregója, és „tehetetlenül nyugtázza, hogy saját szerzői, művészi terrénumának szélére sodródott”. (208.) Ráadásul hiába keresi az igazi értéket és hitelességet, 
ennek állandó ismételgetése a „saját maga szubverzív visszhangjává alakul át, melynek érvényességét ironikusan kérdőjelezi meg a kényszeres ismételgetés kontextusa”. (210.) Ebben az összefüggésben, azaz az indulás (az 1960-as évek) és vég (a 2007-es darab) tükrében számos kérdés felmerül tehát Shepard személyes életmüvére vonatkozóan, de - tágabb értelemben - a posztmodernnel mint stílussal, művészi eljárási móddal kapcsolatosan is, melyek kidolgozása elmaradt.

Amerikai drámakritikára vállalkozó irodalomtörténész mindig szembesül azzal, hogy az irodalomelméletek vagy egyáltalán nem tárgyalják a drámát mint müfajt, vagy a közlés csupán érintőleges. Jóllehet, léteznek historikus és ahistorikus alapú drámaelméletek, de az alkalmazásuk nehézkes, mert ezek vagy egy adott korhoz kötöttek, vagy meglehetősen bonyolult, elvont formák leírását követelik meg. Shepard és az elödök, valamint Shepard és a kortársak kiválasztott szövegeinek az elemzéséhez ezért Varró sem választ drámaelméletet, ehelyett megtalálta a számára leghatékonyabb módszertani eljárást: „az összehasonlító irodalomtudomány eszköztárát”. (19.) A rendkívül alapos és sokrétü elemzések alátámasztják a vizsgálat módszertani helyességét. Ugyanakkor a szerző adós marad a drámakritikában alkalmazott komparatisztikai vizsgálatok elhelyezésével és jogosságának megindoklásával. Bár jelzi, hogy bizonyos irodalomelméleti iskolák eredményeit beépítette a vizsgálataiba, az interdiszciplinaritásról nem tesz említést. Az elméleti alapvetésből kitünik, hogy a szerzőnek nem kifejezett célja drámai stílusok, irányzatok és müfajalkotó elemek behatárolása, mégis szinte elkerülhetetlenül minden elemzés hozadéka (lesz) a Shepard-szövegek posztmodern jegyeinek meghatározása, valamint a modern és posztmodern dráma közti különbségek definiálása. Shepard „posztmodern mivoltának” meghatározása tehát mintegy mellékterméke a komparatisztikai vizsgálatoknak, de maga a szerző elkerüli az állásfoglalást Shepard és a posztmodernizmus viszonylatában.

Az első fejezet a nagy amerikai drámai elődök, O’Neill, Miller és Williams hatásait vizsgálja Shepard egy-egy müvében; a második tömb Shepardot a kortárs Chaikin, Van Itallie, Mamet és Albee írókkal állítja párba; míg a harmadik Beckett „árnyait” tárja fel. Az elemzésre kiválasztott hét alkotás lényegében tükrözi a drámaíró pályájának jól elkülöníthető három szakaszát, a kezdeti kísérleti időszakot (Csörgőkígyó hadmüvelet, 1970), melyet a hazai és a nemzetközi hírnevét megalapozó, ma már klasszikusnak tartott drámái követnek az 1980-as években (Az elásott gyermek, 1979; Hamisitatlan vadnyugat, 1980; Szerelembolondja, 1983; Hazug képzelet, 1985), és a harmadik, az utóbbi évtizedben született müvei (A pokol istene, 2004; Kicking a Dead Horse [Döglött ló rugdosása], 2007). ${ }^{2}$ Az elemzések érveléseiben utalások történnek az életmü egyéb darabjaira, így a Cowboy Mouth (1971), The Tooth of Crime (A bün méregfoga, 1972), Angel City (1976), Curse of the Starving Class (Az az átkozott éhezés, 1978), Eyes for Consuela (Szemeket Consuelának, 1998), The Late Henry Moss (A néhai Henry Moss, 2000) címü művekre.

\footnotetext{
${ }^{2}$ A dátumok az amerikai bemutatót jelzik, kivéve a dublini Abbey Theatre-ben színrevitt Dead Horse-t.
} 
A kiválasztott művek szembesítésében Varró igyekszik elkerülni a Shepard recepciójában gyakorta tárgyalt színmüveket és azok szempontrendszerét. Így az ơneilli örökség feltárására szánt két esszében nem a széthulló és a lelki traumáktól szenvedő amerikai család vizsgálata áll a középpontban, ${ }^{3}$ hanem a férfi és a női karakterek tudati folyamatábrázolásának sajátosságai (O’Neill Vágy a szilfák alatt és Shepard $\mathrm{Ha}$ zug képzelet címü darabjának párba állításában); míg az Emperor Jones (Jones császár - 1920) és a Csörgőkígyó hadmüvelet a kulturális másság konstruálását tanulmányozza. Varró érvelése szerint O’Neill és Shepard egyaránt beépítik az adott kor pszichológiai ismereteit, valamint személyes traumáikat a szereplőik mélylélektani ábrázolásába, viszont lényeges különbségek észlelhetők a férfi és a női psziché és ösztönök közötti polarizáltság kifejezésében. Az „elme nem-esítésének” (31.) dramaturgiai megjelenítését a "tér, a téma és a kulturális mítoszok szintjein” (32.) végzett részletes szemiotikai vizsgálat mutatja be. Ennek eredményeképpen jól elkülönül a modern és a posztmodern identitás felfogása: míg „O’Neill esetében az identitás teljes egész és körülhatárolt, addig Shepardnél az identitás darabokra szakadt, és minden rész belsőleg tartalmazza a több fajta gender-azonosság potenciálját". (38.)

A tér pszichológiai töltése ugyancsak hangsúlyozza a modern és posztmodern identitás, valamint a gender megképzettségének jellegét: a Vágy a szilfák alattban vertikális osztású lesz, hiszen „a felső szoba a tudatos én, az alsó a tudattalan, az ösztön birodalma”, ezzel szemben „a posztmodern dráma a pszichét inkább horizontális tagozódással jeleníti meg". (41.) A Hazug képzeletben a házaspár (Beth és Jake) közötti szakadékot, „ezeket az erőket, archetípusokat, pszichológiai ösztönöket két teljesen különálló pódiumra helyezi el" Shepard (42.). Varró érvelése szerint a fényhatásokkal és a párhuzamos jelenet-kompozíciókkal kiegészített pódiumelkülönítés jól szimbolizálja „az egyetlen énen belüli hasadást is [...], csakúgy, mint a két teljesen különálló identitást" (43.), így a széttördelt személyiség szcenikai megjelenítését állítja a középpontba. A látszólag pszichológiai dráma mindkét szerzőnél igen mély társadalomkritikát rejt, azaz közvetlen kapcsolat van a szereplők belső világa és az őket körülvevő társadalmi közeg között. A férfi psziché torzulása és perverziója összeköthető „a mítoszi tudat hanyatlásával”, az olyan amerikai mítoszok eltűnésével, melyekben „a férfiak hősök [...] voltak". (52.)

A komparatisztikai vizsgálathoz kiválóan összeillő drámapárnak bizonyul a Jones császár és a Csörgőkígyó hadmüvelet: olyannyira, hogy a szerző Shepard művét az O’Neill-darab átiratának tekinti. A másság térbeli, időbeli és ideológiai konstruálásának Michael Pickering szerinti értelmezése adja a keretét Varró mélyreható elemzésének. Végső megállapítása, hogy a másság nem rasszban fogant kérdés a darabokban, hanem az 1920-as és 1970-es évekre konkrétan vonatkozó társadalomkritikát

\footnotetext{
${ }^{3}$ Tipikus példa a széteső család vizsgálatára Henry I. Schvey tanulmánya (The Master and his Double: Eugene O'Neill and Sam Shepard, Journal of Dramatic Theory and Criticism, 1991/2, 49-60), amely a Hoszszú út az éjszakába és Az elásott gyermek címủ darabokat veti össze.
} 
hordozó dramaturgiai eszköz, mellyel mindkét író az amerikai idealizmus és demokrácia „sarokkövének számító” Amerika „kiválasztottság-mítoszának” (61.) letünését ábrázolja. Valójában az USA expanziós politikáját kritizálják, hiszen a müvek pontosan elhelyezhetőek az USA történelmi, reálpolitikai közegében: a Jones császár Haiti 1915-ös elfoglalására utal, míg a Csörgőkígyó hadmüvelet a vietnami háborúra és a hidegháborús fegyverkezési versenyre. Az „átirat” fogalma tehát jogos, hiszen mindkét müvet áthatja a politikai irónia és pesszimizmus.

The God of Hell (A pokol istene, 2004) címü Shepard-darabban felbukkanó ügynök, Welch alakja kiindulópontul szolgál ennek a típusalakzatnak a tanulmányozására az amerikai drámában. Kitekintéssel a 20. századi amerikai regényirodalomra, Varró átfogó és sokszempontú elemzést ad a „házaló vagy vándorkereskedő” (65.) megjelenéséről és változatairól Theodore Dreiserrel kezdve Sinclair Lewison át F. Scott Fitzgeraldig, majd részletesen taglalja az ügynökfigura transzformációit O’Neill, Miller, Mamet és Shepard vonatkozó műveiben. A milleri életművön belül felbukkanó ügynökfigurákból viszont kimaradt egy igen fontos Willy Loman ügynök-reinkarnáció, Lyman Felt a Londonban bemutatott The Ride Down on Mt. Morgan (Lefelé a hegyröl, 1991) című drámából. Mivel a szerző Lomant nevezi meg alapmodellnek az ügynökfigura további drámai megformálásához, $A z$ alku (1968) Solomonját az archetípus felelevenítésének tartja, az 1980-as évek önző lelkületü Amerikáját megtestesítő gátlástalan bigámista biztosítási ügynök nem hagyható ki a sorból. Az ügynök halála Lomanje 1949-ben erkölcsi értékekkel még rendelkező tragikus sorsú hős, aki önmaga vet véget az életének, a harminc évvel későbbi Lyman viszont Loman minden hájjal megkent, erkölcstelen mutációja. Lyman túlélő, ugyanolyan „manipulatív szélhámos" (76.), mint Shepard antihőse, Welch A Pokol istenében.

Shepard Hamisitatlan vadnyugatának tematikai gazdagságát, sokrétüségét bizonyítja, hogy különböző szemszögből a kötet három tanulmánya is foglalkozik ezzel a művel. Az első nagy fejezetben a szerző Miller Alkujával veti össze az árulás és cserbenhagyás témakörébe építve. A szülő, a testvér és a múlt elárulása a szereplők személyes életében menthetetlenül összekapcsolódik az egykor volt nagy nemzeti mítoszok kiüresedésével és eltűnésével. Az egyéni kórkép jelzi és egyben tükrözi is a társadalmi kórképet, így aláhúzva az egyén társadalmi felelősségét, mely mindkét írónál visszatérő téma. Finomításra szorul viszont Miller drámairodalmi kötődésének sommás leírása, miszerint őt „inkább a realista [...] irányzathoz szokás csatolni” (79.), ami igaz, ugyanakkor az amerikai drámakritikában a drámai realizmus igen sokféle és tág értelmezésű: gyakran a 'pszichológiai, 'naturalista, 'költöi' jelzőkkel társul, sőt - még az önmagában ellentmondásos formula - a posztmodern realizmus is előfordul a jellemzésekor. Miller maga a realista dramaturgia egyik megújítója, hiszen éppen ikonikus alakjának, Willy Loman belső küzdelmeinek, lelki válságának dramaturgiai ábrázolása kérdőjelezi meg a realizmusát. A megtört állapotba került ügynök látomásai, múltbeli emlékei megelevenednek a színpadon és egyidejűleg szerepelnek a jelen eseményeivel, így érzékeltetve a múlt állandó jelenlétét a jelen döntéseiben, va- 
lamint a belső világának kivetítődését. A térbeli és időbeli szinkronitás technikáját a Ride-ban még gyakoribb kép- és szövegváltásokkal fejleszti tovább Miller Lyman kettős identitásának megjelenítésében.

Tennessee Williams költői realizmusa, szimbólumokkal telített drámája, valamint szereplőinek mélylélektani ábrázolása könnyen kínálkozik Shepard hasonló jegyekkel rendelkező drámáinak összevetéséhez. Varró azonban a két író műveinek szimbolikájában, utalási rendszerében állandóan visszatérő régió-specifikus mítoszok (Dél, Nyugat és Közép-Nyugat) keletkezését, változását követi és értelmezi James Clifford kontaktzóna fogalmának és Virágos Zsolt mítoszelméletének felhasználásával, több darabra vonatkoztatva: Williams Üvegfigurák (1944), A vágy villamosa (1947), Shepard The Tooth of Crime (A bün méregfoga, 1972), Hamisitatlan vadnyugat, Szerelembolondja és $A z$ elásott gyermek. A kontaktzóna alkalmasnak tünik a mítoszok térbeli mozgásának megvilágítására és a drámai karakterek sorsának felvázolására, a rendszerezett mítoszelmélet segítségével viszont a régiókhoz kapcsolódó különböző jellegű mítoszok tartalmi vonatkozásait, életciklusukat, kulturális kódokká változását lehet feltérképezni. A vizsgálódás végső következtetése a modern és posztmodern kor mítoszmentésének különbözőségét emeli ki: a modernista Williams a mítoszok visszaállítására törekszik, a „karakterei még kísérletet sem tesznek arra, hogy átlépjenek a zóna másik oldalára”. (104.) Ugyanakkor Shepard igyekszik a régi mítoszokat átmenteni egy új korszak új diskurzusába és a „mitikus Nyugatának [...] hősei mind arra törekednek, hogy a másik oldal túlélő eszköztárát magukévá tegyék, [...] a hösei képesek kódot vagy helyet cserélni". (105.)

A könyv második nagy egysége a kortársak - Chaikin, van Itallie, Mamet és Albee - Shepardre gyakorolt hatását vizsgálja. Itt további két alfejezet foglalkozik a Hamisítatlan vadnyugattal; a Jean-Claude van Itallie The Serpent (A Kígyó, 1969) címü szövegével való összehasonlítás a bibliai Káin és Ábel történet újraírásának kétféle megközelítését vizsgálja, míg Mamet Segíts minket, Urunk! (1987) című színművel történő összevetés Hollywood demitizálásának drámai megvalósítását állítja a középpontba. Az első elemzés a posztmodern kompozíciós stratégia, az intertextualitás müködésének elve szerinti szövegtranszformációk létrejöttét követi, azt, hogy miként módosulnak a karakterek és íródik át az ősi mítosz a Joseph Chaikin vezette Open Theater (Nyitott színház) ${ }^{4}$ és van Itallie együttműködésén alapuló performanszban. Ez a rész közvetve igen fontos adalékokkal szolgál az 1960-as évek alternatív színházi törekvéseinek megértéséhez, melyek célja a visszatérés a rituális közösségi színházhoz - a realista irányultságú polgári illúziószínházzal való szembefordulás jegyében. A színházi reprezentáció megkérdőjelezése együtt járt a szerző, a színész, a szöveg és a befogadó/néző szerepének radikális átértékelésével. A fejezet kiváló lehetőséget ad

\footnotetext{
${ }^{4}$ Bár a Sheparddal együtt dolgozó alternatív színházak nevei már korábban előfordulnak a kötetben (14, 24, 34.), csak a 119. oldalon jelenik meg a magyar fordítás is: Nyitott Színház (Open Theatre) és Eredet/Teremtés Színház (Theatre Genesis).
} 
annak a megmutatására, hogy Shepard milyen módon használja fel a kísérletező színházak karakterépítő gyakorlatát, hogyan viszonyul az eredetiség, utánzás és szerzőség kérdéseihez, azaz miben áll posztmodernségének esszenciája.

A Hamisitatlan vadnyugat és a Segíts minket, Urunk! összehasonlításában a kulcsszó Hollywood, ahová mindkét dráma szereplői igyekeznek bejutni, mindenféle becstelen, erkölcstelen, manipulatív, sőt eröszakos eszközzel. A drámaírók maguk már többféle funkcióban (rendezö, forgatókönyvíró és színész) megtapasztalták Hollywoodot, ezért is különösen éles a bírálatuk az amerikai szórakoztatóipar fellegváráról. A szerző értelmezésében Hollywood mitikus határvidék, „az amerikai álom egyik verziója", az ígéret földje, ahol mindenki megcsinálhatja a szerencséjét. Ezt a mítoszt kíméletlenül bontja le mindkét író, és Hollywood „a valóság, az emberség, az igazi érték tagadásává" (151.) válik.

$\mathrm{Az}$ amerikai nemzet- és tudatformáló alapító mítosz, az amerikai álom személyes felemelkedési, valamint család- és otthonteremtő vetülete áll a vizsgálódás középpontjában a ma már klasszikusnak számító Albee Az amerikai álom (1961) és Shepard Az elásott gyermek címü műveinek összevetésében. A szerző meglátása szerint mindkét „tematikus szál szövegbeli megjelenéseiben a csonkítás, megcsonkolás toposzai dominálnak". (25.)

Az Ír kapcsolat: Beckett árnya című befejező rész két alfejezete egyetlen Sheparddarab, a dublini Abbey Theatre-ben 2007-ben bemutatott, kifejezetten Stephen Rea ír színész számára írt Kicking a Dead Horse több szempontú tanulmányozására vállalkozik. Az első esszében a szerző egyrészt igyekszik megindokolni Shepard új keletünek tűnő vonzódását az ír színházi gyökerekhez, másrészt igen alapos történeti áttekintést ad a clown típusalakzat keletkezéséről, színpadon és filmen egyaránt. Ezt követi ennek az archetípusnak a részletes elemzése, transzformációinak és funkcióinak áttekintése Beckett Godotra várva (1952) és Shepard Kicing a Dead Horse című darabjaiban. Varró meggyőző érveléssel hangsúlyozza a kitaszítottnak ábrázolt bohócok társadalomkritikai szerepét: „,a maguk módján mindkét darab bohócai kritikus kommentárt fogalmaznak meg helyzetükkel kapcsolatosan és azzal a rendszerrel kapcsolatban, mely öket fogva tartja.” (196.)

A Zárszó: Kicking a Dead Horse, temetések és feltámadások címet viselö kötetzáró fejezet a könyvben kirajzolódó Shepard-portré keretéül szolgál, mivel a dráma fö vonalát alkotó szembenézés a múlttal és az újrakezdés rímel a könyvben használt hagyomány és eredetiség vezérszálára felfüzött vizsgálódási elvvel. A tragikomikus hangvételü darabban Shepard megteremti önmaga alteregóját Hobart Struther egykor sikeres New York-i műkereskedő alakjában, és egyfajta leszámolást végez. A shepardi kánon minden eleme megjelenik a földrajzi régióktól kezdve a szokásos ikonikus motívumokon át a mítoszokig. A mesterek közül visszatérnek Shakespeare, Beckett és Miller árnyai. Vitázva az uralkodó kritikai nézettel, miszerint Shepard „végső leépülését” mutatja a darab, Varró úgy véli, ez a „paródia tárháza”, és a megújulást sejteti Shepard ironikus, öngúnnyal teli hangja, valamint az intertextuális játékok sora. A 
dráma végén Struther maga is bemászik a döglött lovának ásott sírba, de a ló feje - sokat sejtetően - kimaradt.

Varró Gabriella a Mesterek árnyékában: Sam Shepard drámái és a hagyomány címü kötete lényegi szempontokra támaszkodva, hiteles elemzésekben mutatja be Shepard hagyományok tiszteletére épülő, mindig megújuló drámaművészetét, így méltó módon ünnepli a drámaírót születésének 70. évében.

Drága Gabi!

Hálásan köszönöm Neked, hogy mint kollégád és barátod beavattál a Shepard-könyved megálmodásába, és megosztottad velem - kevéssel 2013 karácsonya előtt - a megvalósulásakor érzett határtalan örömödet. Külön köszönet a megtiszteltetésért, hogy még akkor felkértél a recenzió megírására. Mérhetetlen most a fájdalom, mivel már nem olvashatod az elismerő szavakat. A kutatói fegyelmed és a téma iránti rajongásod azonban örökre itt marad velünk, és az írásodban mindig fogjuk hallani a világosan érvelő és mosolygós „,varrógabis” hangot.

Németh Lenke 